\title{
HELYI GAZDASÁGFEJLESZTÉS BAZSI KÖZSÉGBEN
}

\author{
Kápolnai Zsombor - Takács Kristóf - Takács László
}

\section{SUMMARY}

In the last few years, an impressive economical progress has been noticeable in Bazsi, this little village in Veszprém county: for example, the incomings of the local government has been increasing etc. These results can be explained as the effects of the local economic development that the local government started about ten years ago. This development is based mostly on the agricultural traditions of the settlement: by the local system of public works, the local government is growing native apple species and cucumber, and this system seems to become sustainable in medium-term. In this study, we analyze the background of this progress; to reach this object, we have made interviews with the people who are important in the local economy and we have analyzed the significance data that are available in this subject.

\section{BEVEZETÉS}

Az utóbbi néhány évben egyértelmüen pozitív változások voltak megállapíthatók Bazsinak, ennek a 2012-ben mindössze 388 föt számláló Veszprém megyei kisközségnek a gazdaságában: az önkormányzat saját folyó bevételei, illetve ezen belül a helyi adóbevételek szignifikánsan megemelkedtek, a nyilvántartott álláskeresők aktív korú népességhez viszonyított aránya a kedvezötlen országos és nemzetközi gazdasági környezet ellenére nem emelkedett meg drasztikus mértékben. Ezen kedvező tendenciák kialakulásának a hátterében valószínüsíthetően nagy szerepet játszik a községben elindított helyi gazdaságfejlesztési program, amely számos tekintetben pozitív hatást gyakorol a település társadalmi és gazdasági életére.

Tanulmányunk első részében áttekintjük a helyi gazdaságfejlesztési tevékenységek megjelenésének és átalakulásának folyamatát, majd bemutatjuk a Bazsiban végrehajtott lokális gazdaságfejlesztés fontosabb elemeit. Ezt követően elsősorban kvantitatív módszerek segítségével elemezzük a településen nagy valószínüséggel ezen programnak a következtében kialakult eredményeket, majd összegezzük tanulmányunk legfontosabb következtetéseit. (A kutatás a Közösen a Jövő Munkahelyeiért Alapítvány támogatásával készült.)

\section{A HELYI GAZDASÁGFEJLESZTÉSI KEZDEMÉNYEZÉSEK MEGJELENÉSE ÉS ÁTALAKULÁSA}

A Világbank a lokális gazdaságfejlesztési kezdeményezések megjelenését az 1960as évekre teszi, ugyanakkor a kezdeményezések jelentős változásokon mentek keresztül az utóbbi öt évtizedben, köszönhetően a különféle globális átalakulásoknak, melyek hatása vitathatatlan. Az ilyen hatások közé tartozik az 1970-es évek olajválságai és az azok által elindított gazdasági szerkezetváltás a fejlett országokban, az európai integráció bővülése és mélyülése, valamint természetesen napjaink világgazdasági válsága is. Közép-Kelet-Európában az 1990-es évek elején bekövetkezett gazdasági és politikai orientációváltás következtében megjelent új problémák - elsősorban a munkanélküliség 
megjelenése, korábbi sikeres iparágak leépülése - nyitottak teret a helyi gazdaságfejlesztés kezdeti lépéseinek. (A háztáji gazdálkodást joggal értelmezhetjük egyfajta sajátosan magyar helyi gazdaságfejlesztési kezdeményezésként is.) Magyarországon a területfejlesztésről szóló 1996. évi XXI. törvény szövegében a találunk elöször utalást rendszerváltozás után a helyi gazdaságfejlesztésre (ha nem is ezen a néven konkretizálva). A helyi gazdaságfejlesztés elméleti megközelítésként nemzeti minimumként is tekinthető, mivel az eltérő ideológiák mentén szerveződő politikai pártok egyaránt szerepet szánnak a HGF-nek (Rapkay et al 2013).

A helyi gazdaságfejlesztés definíciói közül véleményünk szerint Mezei Cecíliáé áll legközelebb a magyarországi gyakorlathoz: „,a helyi gazdaságfejlesztés olyan a helyi gazdaság életébe történő külső és/vagy belső erőforrásokat hasznosító, tudatos beavatkozás, melynek kezdeményezője lehet külső szereplö is (pl. kormányzat, EU, külföldi töke), de a folyamat kulcsa mégis a helyi szereplök részvétele, akik vagy kezdeményezőként, vagy a külső fejlesztési elképzelés elfogadóiként és alakítóiként lépnek fel" (Mezei 2006).

A Magyarországon igényelhető támogatási formák közül számottevő pénzügyi forrás kifejezetten a helyi gazdaságfejlesztés bővítésének céljából eddig még nem volt elérhető. Kivételt jelent ebből a szempontból az Európai Unió 1991-ben indított LEADER (A vidéki gazdaság fejlesztését célzó intézkedések összekapcsolása) programja, ami „az integráció legsikeresebb közösségi kezdeményezésévé vált" (Hogyor 2010), bár a helyi gazdaságfejlesztés nem pusztán csak a vidéki területeken valósul meg (mindamellett, hogy kétséget kizáróan ez a fö célterülete). Számos kezdeményezés a városokból, akár a fövárosból (pl. a Szatyor Egyesület értékesítési rendszere) indul ki, amely semmilyen szempont vagy lehatárolás alapján nem nevezhető vidékies térségnek.

Az Európai Unió 2014-20-as költségvetési időszakában a gazdaságfejlesztés kiemelt teret kap majd csakúgy, mint az uniós források hazai elosztásában. A hazai tervek szerint az Európai Unióból érkező támogatások 2/3-a áll majd gazdaságfejlesztési célok elérésének rendelkezésére (Faggyas 2012). A helyi gazdaságfejlesztési programok számára az EU térségi integrációs eszközei, az ITI (Integrált Területi Beruházás) és CLLD (Közösségvezérelt Helyi Fejlesztés) biztosíthat anyagi forrásokat a jövőbeni továbbfejlödés reményében (Péti et al. 2012). Az ITI-k olyan funkcionálisan egymáshoz kapcsoló térségekben, mint a Balaton és környéke, helyi gazdaság fejlesztésére is lehetőséget is biztosíthatnak. A CLLD-k kisebb térségekben a LEADER HACS-okhoz hasonlóan szerveződnek majd a tervek szerint. A hazai fejlesztéspolitika jövőbeni irányait meghatározó Országos Fejlesztési és Területfejlesztési Koncepció (OFTK) is figyelmet szentel a helyi gazdaságfejlesztésnek. 


\section{A BAZSI LOKÁLIS GAZDASÁGFEJLESZTÉSI KEZDEMÉNYEZÉS ELEMEI ÉS SZEREPLÖI}

A bazsi gazdaságfejlesztési kezdeményezés egyik legfontosabb aktora a Bazsalma Vidékfejlesztési Egyesület, amely 2007-ben alakult meg, vezetője pedig indulásától fogva Szentes László, a helyi polgármester. A civil és az önkormányzat együttmúködése során célul tüzték ki a helyi termékek számának bővítését valamint az élelmiszerfeldolgozás helyi lehetőségének megteremtését.

A helyi gazdaságfejlesztés eszközei alapvetően két csoportra oszthatók: vállalkozásfejlesztés és az abszorpciós képesség javítása (Shragge 1997 alapján G. Fekete 2011a). Bazsiban az abszorpciós képesség javítását szolgáló eszközök közül a tudatos vásárlói szokások alakítása valamint a közösségi beszerzések helyben tartása valósultak meg.

Ezen civil szervezet és a helyi önkormányzat szoros együttmüködésének volt, amelynek során több mint kétezer őshonos, tájjellegü facsemetét osztottak szét Bazsi, illetve a környezö települések (Zalaszántó, Sümegprága, Sümegcsehi) érdeklődő lakosai között annak érdekében, hogy a térség nagy múltú gyümölcstermesztési hagyományait felelevenítve (amelyek az elmúlt néhány évtizedben szignifikáns mértékben veszítettek a lokális gazdasági rendszerben betöltött jelentőségükböl) a mezőgazdasági tevékenységek köréből kikerült földterületeken ismét megkezdődhessen a produktív hasznosítás. Ehhez a müvelethez kapcsolódóan, azt megelőzve történt meg a helyi öshonos almafatípusok összegyüjtése és tudományos igényü azonosítása, amelynek eredményeként $120 \mathrm{db}$, összesen tizenkét különbözö fajtához tartozó almafát telepítettek génbankba. Kialakítottak egy gyümölcsfeldolgozó egységet is a községben, amelynek segítségével bármely helyi lakos gyümölcslevet állíthat elő terméséből, az esetlegesen keletkező felesleget pedig korlátozás nélkül értékesítheti.

$\mathrm{Az}$ almatermesztéshez köthető tevékenységek mellett a szervezet profiljának másik fö összetevője az őshonos magyar baromfifajták tenyésztésének megszervezése a településen: hét különböző fajtájú baromfiból összesen 2500 darabot osztottak szét a lakosság körében, így kívánva a lakosok között feléleszteni hagyományaikat, és újból meghonosítani a tradicionális falusi gazdálkodás alapjait. Fontos kritérium volt, amelyet az egyesület fogalmazott meg a jövőbeni kisállattartók irányában, hogy lehetőség szerint próbáljanak meg ragaszkodni a természetes szaporítási módszerekhez; ugyanakkor engedélyezték az egyes háztartások személyes szükségleteinek elözetes túlbecsüléséből adódó felesleges baromfik adásvételét is.

A leendő baromfitartók kiválasztása nem szociális alapon történt, mivel az egyesületnek és az önkormányzatnak egyaránt szándéka a helyi mezőgazdasági hagyományok felélesztése ezáltal a helyi gazdaság alapjainak megerősítése a későbbi továbbfejlődés reményében. Az őshonos fajták meghatározása az úgynevezett mintafalu program keretében valósult meg, amelynek eredményeképpen az önkormányzat saját tulajdonában lévő területeken aktuálisan összesen 160 baromfipéldány gondozása zajlik. Ezen tevékenységben nagy 
segítséget nyújt az utóbbi években kialakított keltetőhelyiségek alkalmazása, amelyek számos más fejlesztéshez hasonlóan a helyi közmunkaprogram keretében kerültek felállításra. Fontosnak tartjuk megemlíteni, hogy a település vezetése a közmunkaprogram nem tekinti a helyi gazdaságfejlesztés eszközének, azonban olyan pénzügyi forrás, mely a pályázatokkal szemben, az utóbbi öt év tapasztalatait figyelembe véve folyamatosan rendelkezésre áll. A programban résztvevők folytán a Bazsiban megvalósult helyi gazdaságfejlesztési kezdeményezések szociális gazdaság irányába mutatnak, azonban a közmunkások ezen programmal történő segítése nem elsődleges célja a település vezetésének. Mivel a közmunkások bérezése között nem tevékenységük, hanem végzettségük alapján lehet a jövedelmet tekintve különbség. Az értékteremtő közmunka tehát nem jár a munkások számára közvetlen anyagi elönnyel, azonban a szemléletformálás, munkájuk megbecsülése olyan lehetőség, melyet kihasználva nagyobb esély térhetnek vissza az elsődleges munkaerőpiacra.

A Magyarországon jellemző szociális gazdaság irányába mutató twevékenységek közül (szociális földprogramok, szociális szövetkezetek, nonprofit foglalkoztatási projektek, helyi pénz körök) lényegében egyik sem kívánták megvalósítani Bazsiban (G. Fekete 2011b).

A 2013-as évben 4 tonna uborkát termesztettek a polgármesteri hivatal mögött kialakított gazdaságban, amelynek kialakítása során kordonos megoldást alkalmaztak.

A lokális gazdaságfejlesztési tevékenységekhez kapcsolódó rövid és középtávú célkitüzések között megtalálható, hogy az almafélékre vonatkozó kezdeményezésekhez hasonló akciókat valósítsanak meg a szőlö-, illetve a szelídgesztenye-termesztéshez kapcsolódóan is, amelyek helyi termesztése szintén hosszú múltra tekint vissza. Továbbá itt említhető meg az a terv is, amely a baromfitenyésztési program vízi szárnyasokkal való kibővítését célozná meg, ezáltal is sokszínübbé téve a községi termelési tevékenység arculatát. Más jellegü és egyben nagyobb volumenủ elképzelés a szervezet részéről, hogy belátható időn belül a szükebb környező térségben felmerülö, öshonos baromfik tenyésztésére irányuló igényeket innen kívánják kielégíteni. Mindemellett fontosnak tartják egy kimondottan a helyben előállított termékekre specializálódott bolt kialakítását, hiszen ezáltal jelentős könnyebb lenne a bazsi lakosok által megtermelt mezőgazdasági áru értékesítése.

Tapasztalataink alapján megállapítható, hogy a kezdeményezések megvalósítása során a helyi kontrol (melyet a Bazsalma Egyesület és önkormányzat testesített meg) kellő mértékben megvalósult, azonban a kezdeményezés azon elemei során, melyek esetében a lakosság közvetlen bevonására volt szükség elmaradt a monitoring tevékenység. Ez a megállapítás a baromfi osztásra vonatkozik a monitoring hiányában pusztán lehetőség maradt a lakosság számára kötelezettség nélkül.

Röviden összegezve a megfogalmazott célokat, kijelenthető, hogy a település vezetői számára meghatározott elsődleges feladat a szemléletformálás, hogy megteremtődjenek az alapjai a helyi gazdaság további alulról szerveződő 
bővülésének, amely azonban elképzelhetetlen anélkül, hogy a helyi lakosok magántulajdonukban lévő földterületeiken olyan gazdasági tevékenységet folytassanak, amely saját célra felhasználható, továbbá értékesítésre is alkalmas produktummal (különleges almafajták, egyedi baromfifélék) rendelkezik.

Az önkormányzat szemléletformáló kezdeményezéseinek már megjelentek a spontán követöi Bazsiban a méztermelök, több család kezdett hozzá összefogva és Bazsangó méz néven értékesítik. Az elnevezés a település nevére utal, tehát a jövőben a településmarketing tevékenységének kiterjesztésében is szerepet játszhatnak a helyi termékek (Piskóti 2012).

\section{A BAZSI HELYI GAZDASÁGFEJLESZTÉSI PROGRAM EREDMÉNYESSÉGE}

A helyi gazdaságfejlesztés kulcsszereplőivel, illetve a bazsi lakosokkal folytatott beszélgetések alapján úgy ítéltük meg, hogy a lokális gazdaság fellendítését célzó erőfeszítések nem csak szemléletformáló szerepüket tekintve nevezhetőek eredményesnek; a következökben ezen véleményünk megalapozottságát kvantitatív módszerekkel vizsgáljuk meg. 2002 és 2011 között a bazsi önkormányzat saját folyó bevételei több mint $90 \%$-os növekedést értek el; a tendenciával kapcsolatos részletes adatok a 3. táblázatban találhatóak. Az adatokból megállapítható, hogy a helyi gazdaságfejlesztési program elindulása, amely leginkább a jelenlegi polgármester, Szentes László által a település élén töltött első ciklus kezdetéhez (2002) köthető, egy átmeneti (2003-2004-es) visszaesést követően rövid időn belül érzékeltette kedvező hatását, hiszen már az első ciklus végére, 2006-ra a négy évvel korábbi mutatókhoz képest több mint 30\%-os növekedést sikerült elérni az önkormányzat saját folyó bevételei vonatkozásában. Mindazonáltal kijelenthető, hogy a fejlesztési projekt objektív paraméterek alapján meghatározható kiteljesedése a 2006-tól kezdődő időszakra tehető, amely megállapítás többek között arra az adatra alapozható, hogy 2001 óta 2008-ban rendelkezett a bazsi önkormányzat a legtöbb saját bevétellel, amelynek volumene meghaladta a hét évvel korábbi adat kétszeresét. Az időközben megkezdődött gazdasági világválság hatására 2009-re az előző évhez viszonyítva közel 20\%-os visszaesés következett be, de a 2010-es, illetve a 2011-es adatok ismét a korábbi pozitív tendencia visszatérésére utalnak, amely eredményeképpen 2011-ben a 2008-as kimagasló nagyságú mutatókkal nagyságrendileg megegyezett az adott évi saját bevételek volumene. 


\section{1. táblázat: A bazsi önkormányzat saját folyó bevételei és helyi adóbevételei millió Ft-ban (2002-2011)}

\begin{tabular}{|l|c|c|c|c|c|c|c|c|c|c|}
\hline \multicolumn{1}{|c|}{ Év } & 2002 & 2003 & 2004 & 2005 & 2006 & 2007 & 2008 & 2009 & 2010 & 2011 \\
\hline $\begin{array}{l}\text { Saját } \\
\text { bevételek }\end{array}$ & 6,50 & 5,30 & 5,61 & 6,63 & 8,56 & 9,96 & 12,56 & 10,13 & 11,74 & 12,54 \\
\hline $\begin{array}{l}\text { Helyi adó- } \\
\text { bevételek }\end{array}$ & 4,66 & 3,03 & 3,43 & 3,64 & 4,87 & 6,36 & 8,71 & 7,32 & 8,04 & 10,11 \\
\hline
\end{tabular}

Forrás: a szerzők saját készítése, adatforrás: KSH T-STAR

A települési önkormányzat által begyüjtött helyi adóbevételek alakulásának tekintetében szintén egyértelmüen pozitív változások figyelhetők meg az utóbbi években. A helyi gazdaságfejlesztési program 2002-es elindulása óta a bazsi helyhatóság ilyen típusú bevételeinek nagysága több mint megkétszereződött, továbbá kiemelésre érdemes tény, hogy erre a kedvező tendenciára sem volt hosszabb távú hatással az aktuális gazdasági válság kitörése: egy egyszeri visszaesést követően 2009-től kezdődően folytatódott a növekedés, sőt 2011-ben érte el az eddigi tetőpontját ez a pozitív folyamat. A saját bevételek zömét a helyi adóbevételek teszik ki, a jövőben azonban az önkormányzat szeretné növelni a saját vállalkozásaiból származó bevételek volumenét is, így ez az arány várhatóan módosulni fog.

\section{1. ábra: Az egy főre jutó adóköteles jövedelem nagyságának változása Bazsiban az országos átlag arányában (2000-2011)}

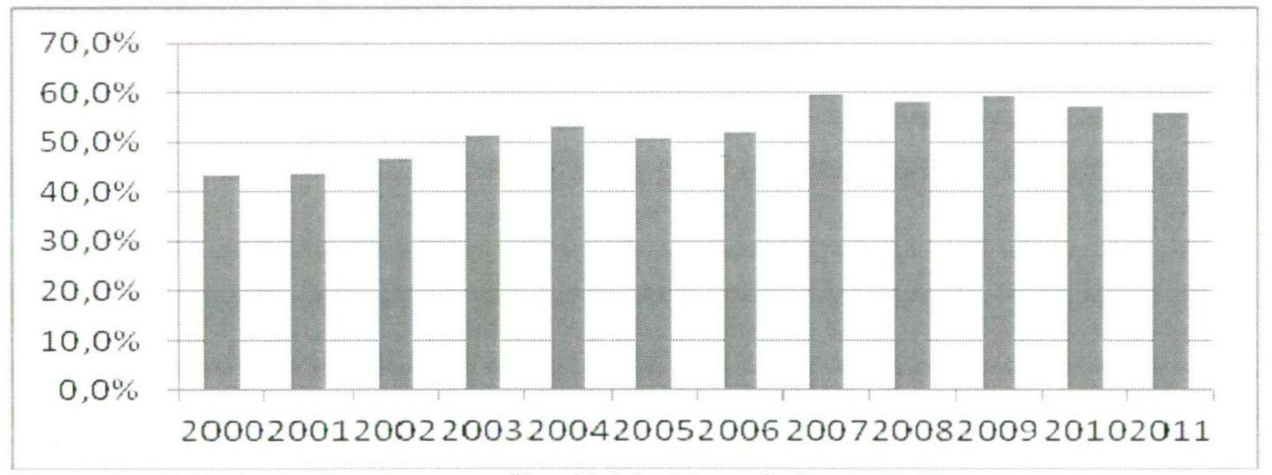

Forrás: a szerzők saját készítése, adatforrás: TeIR

Az egy före jutó adóköteles jövedelem tekintetében (lásd 1. ábra) a XXI. század első évtizedében szintén kedvező tendenciák voltak megfigyelhetők Bazsiban: 2000 és 2010 között rövidebb megszakításoktól eltekintve viszonylag folyamatos volt ezen paraméter viszonylatában a bővülés, amelynek eredményeként (több mint $1 \%$-os éves átlagos növekedés mellett) az évtized végéig $13 \%$-ot is meghaladó 
növekedés valósult meg. Ezeknek a pozitív jellegü változásoknak a kialakulását feltételezhetően nagymértékben elösegítette a községben végrehajtott helyi gazdaságfejlesztési program.

A Bazsiban végrehajtott helyi gazdaságfejlesztési tevékenységek egyértelmủen pozitív hatást gyakoroltak a foglalkoztatás területére is: a nyilvántartott álláskeresők aktív korú népességhez viszonyított arányában (nagy valószínűséggel elsősorban a 2008-ban kezdődött gazdasági világválság következtében) meglehetősen rövid idő alatt (2008 és 2010 között) kialakult nagymértékü emelkedés (lásd 2. ábra) viszonylag gyorsan bekövetkezö konszolidálódásában feltehetően nem elhanyagolható annak jelentősége, hogy a helyi önkormányzat a bazsi gazdaság fellendítésére irányuló törekvései során meghatározó hatásfokkal kezdte kiaknázni a közmunkaprogramban rejlő potenciálokat. Ezáltal a településen élő munkanélküliek száma erőteljesen csökkent, hiszen megvalósult döntő hányaduk integrációja az előbbiekben említett állami projektbe, így a foglalkoztatottság mutatói is pozitív irányba mozdultak el: például a 2012-ben feljegyzett adatok már többé-kevésbé megegyeztek az öt évvel korábbiakkal. ${ }^{22}$

\section{2. ábra: A nyilvántartott álláskeresők aránya az aktív korú népességben, Bazsiban (2000-2012)}

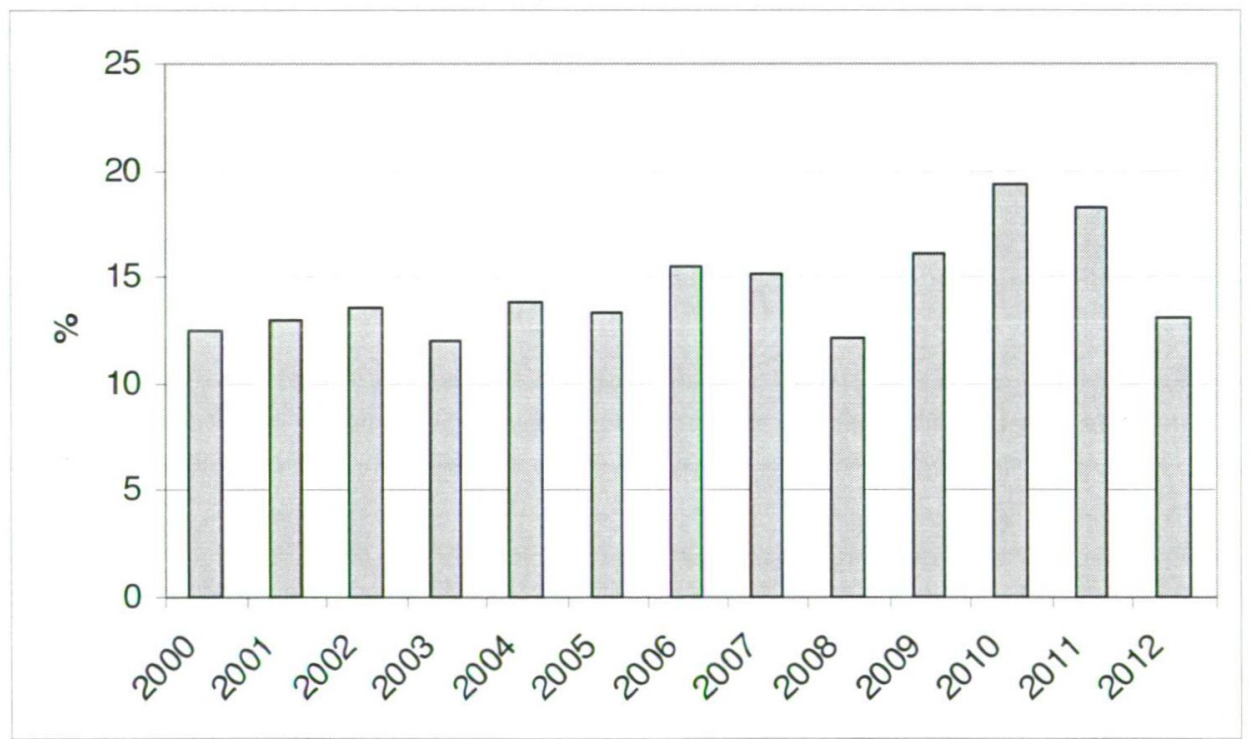

Forrás: a szerzök saját készítése, adatforrás: KSH T-STAR

Feltehetően ugyanezen tényezőre (a közmunkások számának a helyi gazdaságfejlesztés keretében történő megemelkedésére) visszavezethető okok következtében az adott település általános társadalmi-gazdasági állapotát a legtöbb

${ }^{22}$ www.ksh.hu 
esetben nagy pontossággal jellemző indikátorok egyike, a 180 napon túli nyilvántartott álláskeresők száma szintén kedvező változásokra utal az előző részben ismertetett fejlesztési projekt kezdete óta (lásd 3. ábra).

\section{3. ábra: A 180 napon túli nyilvántartott álláskeresők aránya az aktív korú népességben, Bazsiban (2000-2012)}

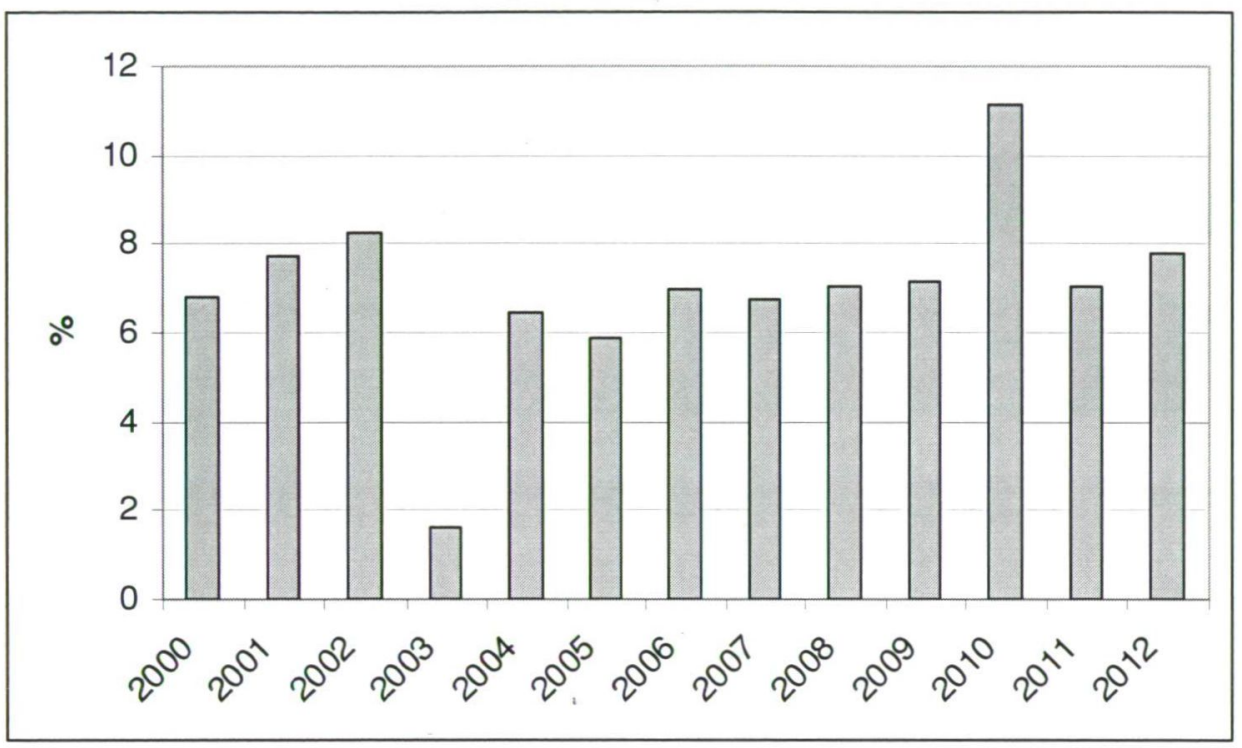

Forrás: a szerzők saját készítése, adatforrás: KSH T-STAR

A kedvezötlen folyamatok, az országos, illetve nemzetközi szinten egyaránt negatívnak minősíthető gazdasági környezet ellenére nem következett be számottevő aránynövekedés ezt a paramétert vizsgálva (eltekintve egy egyszeri kiugrástól 2010-ben, amelyet azonban gyors korrekció követett). Megállapítható, hogy az állást több mint fél éve nem találó regisztrált munkanélküliek hányada az összes álláskeresőhöz viszonyítva kimondottan hektikus változásokat mutatott az elmúlt évtizedben, azonban mindenképpen előnyös adatnak nevezhető, hogy az utóbbi néhány évben sem ment végbe ezen csoport jelentőségének drasztikus megerősödése.

\section{KÖVETKEZTETÉSEK}

A kutatásunkban alkalmazott kvalitatív és kvantitatív módszerek által nyert eredmények egyaránt arra utalnak, hogy a bazsi lokális gazdaságfejlesztési program hatásfoka kimondottan magasnak minősíthető. Külön kiemelésre érdemes adat, hogy a települési közmunkaprogram keretében - számos negatív példával ellentétben - gyakorlati haszonnal rendelkező tevékenységek elvégzése valósul meg, így az ebben a vonatkozásban végbemenő fejlesztések szerves módon képesek bekapcsolódni az egyéb keretek között megvalósuló, kedvező irányú 
változásokba. Szintén egyértelműen pozitívnak minősíthető az a szemléletbeli sajátosság, hogy a helyi gazdaságfejlesztés kulcsszereplöi középtávon szeretnék piaci úton finanszírozhatóvá tenni az eddig végbement fejlődés hatásait, elismerve, hogy jelenleg a kívánatosnál nagyobb szerepet tölt be településük gazdaságának fejlesztésére irányuló törekvéseik között a közmunkaprogram, illetve hogy ezen kereteken belül a helyben előállított termékek, gazdasági értékek jelentősége is további javításra szorul. Mindazonáltal ezen hiányosságok figyelembevétele mellett is kijelenthető, hogy a bazsi helyi gazdaságfejlesztési program egyértelmüen követendö példaként állítható hazánk számos hasonló helyzetben lévő és társadalmi-gazdasági paraméterekkel rendelkezö települése elé.

\section{IRODALOMJEGYZÉK}

Faggyas S. (2012): "Térképre és iránytüre is szükségünk van, hogy célba jussunk": Beszélgetés Csizmadia Norbert tervezéskoordinációért felelös államtitkárral a nemzetgazdasági tervezés új kihívásairól és feladatairól. In. Falu Város Régió, VÁTI, 2012/1-2. pp. 21-23.

G. Fekete É. (2011a): A szolidáris és szociális gazdaság elemei a magyarországi helyi gazdaságfejlesztésben. In. Észak-magyarországi Stratégiai Füzetek (2011) VIII. évfolyam 2. szám. pp. 38-56.

G. Fekete É. (2011b): Önkormányzatok és civil szervezetek helyi foglakoztatási kapacitásának növelési lehetőségei. Miskolc.

Hogyor V. (2010): A LEADER program bemutatása a sümegi kistérség példáján. In. Szabó Szabolcs (szerk.): Vidéki térségek Magyarországon. Trefort Kiadó, Budapest.

Mezei C. (2006): A helyi gazdaságfejlesztés fogalmi meghatározása. In. Tér és Társadalom 20. évf. 2006/4. pp. 85-96.

Péti M. - Czene Zs. - Csizmár O. - Gálóczi B. - Petrás F. - Szabó B. (2012): Helyi és térségi gazdaságfejlesztés perspektívái a 2014-2020-as fejlesztési ciklusban. In. Falu Város Régió, VÁTI, 2012/1-2. pp. 87-91.

Piskóti I. (2012): Régió-és településmarketing- Marketingorientált fejlesztés, márkázás. Akadémiai Kiadó, Budapest.

Rapkay B. - Illés S. - Stárics R. (2013): A helyi gazdaságfejlesztés egyes gondolati előzményei és következményei. In. Földrajzi Közlemények, Magyar Földrajzi Társaság, 2013/1. pp. 28-39. 